\title{
Caricaturizing Freedom: Islam, Offence, and The Danish Cartoon Controversy
}

\author{
Ashwani K. Peetush Wilfrid Laurier University
}

\begin{abstract}
I argue in this paper that the publication of cartoons caricaturing Islam by Jyllands- Posten is problematic for a number of reasons. First, within liberal political theory itself, there are reasonable arguments that the depictions (at least two) perpetuate prejudice and verge on hate speech. Second, such depictions weaken the social conditions that make possible a thriving democracy (i.e., participation) by marginalizing the already marginalized. Moreover, the caricatures perpetuate an Orientalist discourse about the nature of Islam and the non-West, and hinder global intercultural dialogue and understanding between nations.
\end{abstract}

\section{Introduction}

The Danish Cartoon controversy confirms that we live in a much smaller world, a more transparent world, where political sovereignty can no longer bear the weight of neo-colonial discourse. What we say and do matters far past the limits of territorial integrity and has global consequences; we are accountable, beyond borders. Intercultural dialogue at the global level, and the social conditions from which it emerges, are fundamental to our interconnected existence. Such conditions are grounded in norms of mutual civility, respect, recognition, and, of course, freedom of speech. In this paper, I argue that, ironically, the cartoons erode the foundations that make possible global intercultural dialogue in the very guise of freedom.

Let me begin by pointing out that the manner in which the controversy has been framed in the media, that of reconciling the global conflict between the 'western' idea of freedom of speech with non-western nations, is problematic. It is grounded in a number of false oppositions that find support in an Orientalist discourse perpetuated by theorists such as Samuel Huntington (1996). As Tariq Ali argues, such false oppositions serve to further exploit formerly colonized nations in a number of arenas (2003). The idea of freedom of expression or speech - conceived of as an avenue for civil and respectful communication, discussion, debate, and criticism is not simply a western ideal. On cursory reflection alone, it is not at all clear to me that such an idea is only historically linked to and developed in Europe. Discussion and dialogue form the basis of many nonwestern cultures around the globe; the Aboriginal peoples of North America and their traditional form of participatory democracy is a good case in point. However that maybe, even if one believes the ideal of freedom of speech can somehow be linked only to Europe, this is certainly no

\section{Keywords}

Islam

Danish cartoon

controversy

freedom of speech

intercultural dialogue 
longer the case. It is certainly misleading to suggest that, here and now, freedom of speech, as an avenue for respectful criticism, is a value only esteemed by western nations. The world we live in is one of borrowing and hybrid mixture, where values, traditions, music, and art fuse in an intercultural mélange producing things of awesome beauty, alongside things we may abhor (such as rampant consumerism).

My aim here will be to provide an argument from within the theoretical and philosophical boundaries of secular liberal democratic principles that problematize the publication of the cartoons. After the demise of the Soviet Union, on a global level, liberal democracy is seen to be the key contender in terms of what it means to organize a society in just terms. Apart from Europe and the West, various non-European countries see this form of polity as a viable and live political option. Thus, I want to show that even within the confines of secular liberalism and democracy, this issue is problematic. As importantly, my objections aim to provide an internal critique because most of those who support the publication of the cartoons do so explicitly on the liberal theoretical basis of 'freedom of speech,' and free democratic exchange. I contend that one cannot consistently hold this position without serious conceptual difficulty. What of non-liberal justifications then? These are numerous and many will be compatible with the position I present here. To be sure, my arguments pertaining to the social conditions required for a democracy (i.e., its transcendental conditions) are foundational to and neutral among both liberal and socialist, or Marxist, democracies. In fact, my arguments have a much wider global scope. I argue that the crucial conditions required for democracy are the same as those required for intercultural dialogue across the globe more generally. Indeed, such conditions are critical to dialogue with non-secular and non-democratic nations of the world.

Along these lines, I argue that the publication of the cartoons caricaturing Islam by Jyllands-Posten is problematic for two basic reasons. First, I contend that there are reasonable arguments that at least two of the depictions clearly perpetuate cultural prejudice and fall under hate speech. As such, I contend that within the parameters of liberal political philosophy itself, there are good arguments against the publication of such material. Second, I argue that the cartoons, and any such caricaturizations, serve only to weaken the social conditions that make possible a thriving democracy (i.e., participation) by marginalizing the already marginalized. Importantly, they weaken the preconditions and possibility of civil intercultural dialogue across the globe generally. Third, I respond to various prevalent objections against my position.

\section{Limits to freedom of speech within liberalism}

I start by exploring the nature of hate speech and whether the cartoons qualify as such. Before I do this, let me note that often theorists implicitly connect any criticism of Jyllands-Posten by minorities to an implicit endorsement of violence against the Danish publishers. Such a connection is fallacious, to say the least. I strongly oppose the use of violence against any person for the publication of controversial material, but that does not mean that I cannot or do not have the democratic right to object to such material. 


\section{Children's stories}

The controversy began when the Jyllands-Posten, the largest paper in Denmark, decided to print twelve controversial editorial cartoons depicting Muhammad with a caption that read: 'Muhammads ansigt' (Muhammad's face) on 30th September 2005. The debate recently re-emerged as eleven other Danish papers chose to reprint the cartoons (February 2008). This is after Danish intelligence allegedly uncovered a plot to kill one of the cartoonists and arrested three men (one of whom was released, and two others deported without trial). The defence of the choice to print and reprint the cartoons has been surprisingly unified by a majority of Danish spokespersons. The defence is grounded on, as the Danish PM Anders Rasmussen contends, the liberal basis for freedom of speech: 'Freedom of speech is the most valuable right to liberty -we must defend it to the very last (Buch-Andersen 2006).'

Jyllands-Posten argues the publication of the cartoons was an attempt to contribute to the debate over Islam and self-censorship. The entire cartoon episode originated with the author of a children's book who was attempting to write a book on the life of Muhammad. He sought an illustrator to depict the story but was at a loss. Danes were purportedly too frightened of the consequences; illustrations of Muhammad are prohibited by Muslims. But, as Joseph Carens points out, this manner of telling the story has a powerful rhetorical appeal (Carens 2006: 36). It casts the origins of the debate as not only benign, but admirable. Here we have a Dane who chooses to engage in the project of intercultural dialogue and consciousness-raising by helping Danish children to learn about a socially, economically, and politically marginalized class. This is a noble and heart-warming task. His project is stopped dead in its tracks by an antiliberal force, which grips Danish consciousness with fear and results in self-censorship.

On deeper reflection, I would argue that the author's project is far from benign. Let us think again. The author is well aware that a wide majority of Muslims object to religious iconography and, as such, illustrations of Muhammad are thought to be disrespectful. If this is the case, then why would anyone deliberately and knowingly present information about another religion in a manner that most of its adherents find explicitly offensive and disrespectful, and this too to little children (some of whom will undoubtedly be Muslim children)? This is by no means a considerate and respectful approach to try and understand and appreciate another's religion. As such, I submit that this is far from a benign or admirable attempt to understand another culture or religion; it is something altogether different. As a response to the difficulty of finding an illustrator, the largest newspaper in Denmark, decides to step in. They decide to publish cartoons depicting Muhammad so as to 'contribute' to the debate on selfcensorship and the fear that grips Danish consciousness. This is where the story takes a more problematic turn. The cartoons are not simply illustrations, but rather depict Muhammad and Islam in a controversial light, to say the least.

Let me examine the nature of the cartoons that Jyllands-Posten decides to publish. There are twelve in total. Some seem unobjectionable and appear to aim at humour and irony. These include Muhammad standing 
in the desert; and Muhammad with a picture of himself and a sign in his turban stating, 'PR Stunt.' There are others that are far more controversial. The two most controversial are: Muhammad is depicted as a suicide bomber, he is shown with a bomb in his turban and a lit fuse with the Islamic creed (Shahadah) written on the bomb; and, Muhammad explaining to a line of suicide bombers to stop because 'we have run out of virgins.' Others include a depiction of Muslim women and a caption that translates as 'Prophet! Daft and dumb keeping women under thumb'; Muhammad with a sword in his hand and two fully veiled women by his side; and Muhammad standing with two demonic looking horns growing out of his turban (as Satan is often characterized).

We should take note also that the publication of the cartoons comes after the Jyllands-Posten refused to publish cartoons that ridicule and caricaturize Jesus, on the basis that Christians might be offended (Madood 2006: 5). Flemming Rose, the editor, justifies the publication of the Muhammad cartoons as an exercise in free speech, nothing to do with an intention to offend or prejudge an already marginalized segment of the Danish population (Rose 2006).

But are these cartoons really that problematic? In what way are they problematic? I certainly understand that the borders of what is acceptable and what is offensive are often a contested and difficult issue for a society, especially in a multicultural environment. But I contend that two of the cartoons (if not more) cross clear enough boundaries and perpetuate a form of prejudice against Muslims, and arguably fall under hate speech. How so?

Let me first discuss the idea of hate speech. Hate speech is a specific form of activity that expresses, encourages, advocates, or promotes hatred towards a group of people or community. Hate includes, among other things, rejection, social alienation, contempt, and may include the desire to harm (physically or otherwise). Such harm may be either active (shouting slogans and burning crosses) or it may be more silent. It may simply rely on the attempt to create a social environment in which the particular target is socially marginalized from social, political, and economic spheres of a society (e.g., Black people in America are a good case in point). There are often two key elements to hate activity. First, a group is singled out on the basis of some primordial identity marker; these are some set of purportedly shared features (real or imagined), such as, but not limited to, race, religion, culture, skin-color, gender, sexual orientation, dress, attitudes, psychological traits, personality, intelligence and the like. These features of group identity may be visible (such as skin color, or gender, or dress) or sometimes may not (sexual orientation). Often, such characteristics are difficult to change without giving up something of critical value (religion, culture) and sometimes they are impossible to change (skin color, race). In fact, it serves victimizers well to pick characteristics that are not malleable. Second, the group is then branded as inferior, disgusting, dangerous, and inherently inferior on this basis of such singling-out features and markers. This branding, and consequent ostracization and social alienation, is often based upon prejudice and demeaning stereotypes.

Let me emphasize that hate speech is not simply speech, but rather an activity. Such activity can be promoted, and sometimes best promoted by 
symbols (such as the Nazi Swastika). Furthermore, hate speech does not necessarily result in outward mayhem or social disorder (as in street fights or bombing). It can simply be aimed at producing a chilling climate of subtle discrimination, in which the targeted party can no longer live or raise their children comfortably. But this does not mean that the more silent activity is by any means less extreme or less problematic or inert. In fact, discrimination is often more deadly this way, as one can never put a finger or point out the prejudice.

The two cartoons I have mentioned previously satisfy the criterion for hate speech. Both cartoons pick out a certain religious group and connect that group, unfairly, with not only violence but terrorism. The representations speak louder than words. The images are symbolically powerful and carry a disturbing message: Islam is inherently a religion of violence and its follower's terrorists. By choosing Muhammad, the cartoons identify not simply another man (for example, if one were to pick Osama Bin Laden or a particular sect of religious extremists), Muhammad is the spiritual founder and forefather of Islam. He represents Islam in much the same way as Jesus represents Christianity and the Buddha represents Buddhism. By placing a lit bomb in his turban and depicting him as a suicide bomber, or by having him greet suicide bombers with an announcement that he has run out of virgins to give them (i.e., their 'just' reward) is not only to intimately connect him to terrorism, as somehow the master kingpin, but to stereotype his followers as terrorists also. It is to link the whole of the community that follows his rules and worships him as a part of their daily life (approximately one billion people) to terrorism. Importantly, this connection is not a matter of extrinsic or contingent fact (i.e., a matter of some extremists interpreting the Koran self-servingly), but intrinsic in nature. Muhammad himself is a terrorist, and thus, ipso facto, his teachings are grounded in violence and terror. His followers are but mere instruments of such terror.

All of this is done without argument, without giving us reasons to support such assertions. Of course, the very nature of caricatures is to offer no arguments, indeed, to cut through the arguments. Yet, I think it is no small matter to brand a whole religion, and peoples, as terrorists, without offering reasons to support such vast overgeneralizations. Nor is this an isolated incident; Muslims have been the target of prejudice and discrimination for some time now. The cartoons serve only to fuel this social climate by perpetuating disturbing prejudice and stereotypes. Such representations are part of a larger historical picture in which the Muslim world is marginalized and alienated as fundamentalist, backward, barbaric and needing to be civilized by the rationally-minded, progressive and freedomloving West.

Now let me ask, what better reason can we have to hate others other than that they, and their whole way of life, is inherently devoted to violence? What better reason can we have to alienate others than the fact that they are, or support, suicide bombers committed to blowing up mothers and innocent babies at grocery stores and park-outings, all in the name of God. Such a group certainly deserves our hostility, our rejection, our outright hate - how could it not? Anyone who follows such a religion ought rightly to be shunned and alienated from participation in the public 
1. In fact, it is difficult to make much sense of Randall's unprincipled arguments at all. While hate in general is not permissible for Randall (whatever would qualify as such in his view), it is entirely unproblematic to express hatred for religion. Why is this the case? Freedom of conscience, and the right to live according to one's comprehensive doctrines (whether such doctrines are religious or not) is foundational not only to liberalism, but basic human rights. This is not to mention that toleration is also a key value for liberalism. sphere of a truly liberal and democratic order. In sum then: the cartoons spread prejudice by perpetuating humiliating, grossly untrue overgeneralizations and demeaning stereotypes that link the entire Muslim world with terrorism and violence. In other words, they spread hate.

\section{Liberalism, freedom, and the harm principle}

Perhaps, I am way off track here. Many object that the cartoons are only a jest, all in good humour. Muslims have to realize that political parody, satire, and humour is a part of the liberal-democratic tradition. I understand political parody, but I would argue that that too has boundaries. Let me ask: what if the caricatures had been about Moses, depicting him as a crooked businessman caught in the act of duping others out of their property? Or, consider cartoons aimed at caricaturizing homosexuals or women? Are these also all in good fun? Most would shout racism, discrimination and sexual harassment. Even humour has some limits. Other peoples' pain and suffering, their social alienation, is not something that should be laughed at, or is it? Many liberals argue that this is the price for living in the liberal democracy, the cost of freedom. Christians regularly have to tolerate and live with all sorts of abuse. Indeed, Rose argues that 'contemporary democracy and freedom of speech' requires that Muslims put up with 'insults, mockery, and ridicule,' for this is the price of a 'modern secular society.' Randall Hansen, a political scientist, similarly argues that:

I am sure it is the case that many Muslims are deeply and genuinely offended by the Danish cartoons, and I sympathize them. But this offence is the price of living in a liberal society.... Elderly Jews, including holocaust survivors, have been told that they could not stop neo-Nazis from marching past their front windows.... they simply had to accept it. So it is with those Muslims who think that their religion is above satire and mockery.

(Hansen 2006: 15-16)

Randall argues that either Muslim citizens and immigrants accept this supposed fact about liberal democracies or, basically, get out: 'they have to decide whether they wish to live in a liberal democratic society,' as free speech 'is a part of the liberal democratic framework, not a negotiable addition to it.' And although Randall himself claims to be against 'hate speech,' it is difficult to see what qualifies his position (given that it is entirely acceptable for me to stand outside an 80 year old holocaust victim's door waving a Swastika in his/her face). ${ }^{1}$

Let me now consider the key issue: should such speech indeed be protected by the state? Many liberals object to this on the grounds that limitations on freedom of speech interfere with individual autonomy, which is a prized value for liberal democratic societies. I contend that such arguments to defend freedom of speech suffer from a number of critical flaws. I point out that no freedoms are absolute. My right to freedom of conscience does not mean that I can offer you as a sacrifice; an individual's freedom is limited by other's freedom. I contend that while most liberals recognize that individual freedom is restricted by the harm principle, many fail to appreciate the depth of psychological and social harm that often results from speech that is degrading, prejudiced, racist, or homophobic. 
How might I philosophically justify the claim that it is entirely unproblematic for me to mock, degrade, or say things that publically humiliate you on the basis of your ethnic, sexual, or religious affiliation - in fact, that this is my legal right to do so, and that you have an obligation, indeed a political duty to not only 'put up' with it, but respect my right as a matter of justice and fairness.

I think that, among others, one of the sources of this view is a particular interpretation of liberalism and how a liberal society is supposed to be constituted (an early John Rawls (1971) - Ronald Dworkin (1984) variant). Let me briefly conduct a conceptual genealogy and examine this brand of liberalism in which such a right may seem naturally to be found. Theorists who defend this view of liberalism argue that the only just society or acceptable form of social organization proceeds along particular liberal lines. Such a society is conceived of as contractarian in nature: people co-exist together on the basis of rational self-interest, which is maximal freedom to live whichever way they want. They often stand in competing and adversarial relations to one another since the prime and overriding value for such a model is individual freedom (my freedom to do what I want may conflict with your freedom to do what you want). If individual freedom is not to be simply empty or formal then it needs to be cashed out in terms of real life social conditions that must be met. The social conditions that make possible individual freedom are factors such as the right to own private property and basic civil and political rights, such as the right to vote, freedom of conscience and the right to free speech.

Liberals disagree among themselves about exactly what such conditions are and require, for example, whether they include a minimal level of subsistence and so on. However that may be, the state of this theoretical model has mainly a procedural role: its job is to arbitrate between citizens when their ends and actions conflict. The state is to remain entirely neutral with regard to views of the good life. The only justifiable limits to individual freedom are another's such freedoms, mostly conceived along John Stuart Mill's harm principle: I am free to do what I want as long as I do not harm others and interfere with their freedom (2008: 5-132). The job of the legal system is to enforce that I do not do so. The clear division between church and state, between law and morality, between the private and public are at the heart of such a society. The state should not be organized around any particular religion or tell me what religion I ought to follow (that is my private business). As well, the state should not be grounded in a particular moral vision of the good life. It is my private business and right to decide if I want to be an ethical egoist or a compassionate human being.

Now, as long as I do not interfere with your individual freedom or harm you (and this is usually interpreted quite narrowly), then I can do pretty much what I want. If I decide that I hate you/your children/your community because you are Jewish (or Black, Muslim, or Native, or a homosexual, and so on) and I would like to march in front of your door carrying banners with large Swastikas, then this is my legitimate and political right, as long as I do not enter your private property, break your windows, or physically harass you. It is a part of my right to freedom of speech. 


\section{Sticks and stones}

I argue that the attempt to defend freedom of speech to this extent is problematic even within such a liberal model of society itself. One may begin by pointing out that no freedoms are absolute and even the staunchest libertarian will have to agree. My freedom and right to own private property does not mean that I am free to steal your stuff; my right to mobility does not mean that I can walk into your house uninvited; my freedom of conscience does not mean that I can use you as a sacrifice, and so on. That is, individual freedoms are weighted alongside other freedoms, no one, in principle, being of an absolute nature. Limits are defined in terms of interference in others' freedoms, or harms caused.

If, in principle, freedoms are limited by interference in other's freedoms conceived along the lines of the harm principle, then why should freedom of speech be excluded? Why should freedom of expression trump all other values? I would argue that one key reason is a 'sticks and stones' type of perspective where speech is thought to be somehow an inert activity, of little weight when compared to action. If I punch you in the face for no other reason than that you are Black, Muslim, or homosexual, then that is an action that clearly and unjustifiably violates your bodily integrity and harms you in a direct manner that interferes with your individual freedom. But if I want to publically spread prejudice and demeaning stereotypes that degrade you on the basis of some morally arbitrary characteristics, and if I want to mobilize my gang to march through your neighborhood carrying banners proclaiming, for example, 'Ni-ers, P-kis, F-gs or K-kes, or Jews/Muslims are dumb, inferior, or terrorists' or something of that nature, then I should be free to do so, and my freedom should be protected by the modern liberal state. I contend that this is unreasonable. The above argument fails to appreciate the depth of emotional, psychological, social, and political harm that often results when speech is degrading, racist, homophobic, or misogynist. Or put another way, speech is not simply an inert activity and can have even more devastating effects that physical abuse; speech is action.

\section{Harm caused by speech}

Such harm occurs at various levels. Targeting people and promoting hate creates a climate of conflict and social instability. In extreme cases, where speech is used not simply to mock a targeted group, but rather to positively spread prejudice, hate and hostility in a systematic manner, the long term effects can be devastating in a number of ways. Such intimidation often condemns members of targeted groups, and their children, to live lives of fear, isolation, and social alienation. This inhibits participation in the wider social and political life of the community that is fundamental to the spirit of democracy and dialogue. It can damage their sense of self-worth and dignity; something essential not only to political participation but to developing one's full life potential or individual autonomy, which is a key value for a liberal society.

As philosophers such as Will Kymlicka (1995) and Charles Taylor (1995) point out, there is an intimate connection between group identity and self-identity. For many people, cultural, religious, and ethnic identity is integral to their sense of self; it provides them with a sense of identity, who they are, what is of value and significance. If a group is 
constantly and systematically demeaned and degraded in the public domain, then individual lives are made far worse. Indeed, as Taylor argues, if people are constantly exposed to negative and depreciatory images and stories about their groups, they may come to actually adopt such images. Individuals, especially children, often internalize the stories that wider society tells them about themselves. They may come to lead lives of self-hatred, self-doubt, and low-esteem. Some may come to live lives of social anxiety, always looking behind their shoulder, afraid to speak their minds, overly concerned about their gestures, accents, dress and physical appearance. This can be debilitating, for even when the formal obstacles to their equal participation fall away, group members may not be able to take advantage of such new found opportunities because of their lack of self-confidence.

Such people are unjustly disadvantaged and cannot fully access the benefits of freedom and equality offered by a liberal society. And, while it may be true that it is difficult to measure the harms caused, it is no doubt real and significant. There is a deep sense of social alienation that comes along with growing up in a prejudiced environment and a huge cost to individual lives (in this regard, see also Richard Delgado and Jean Stefancic, 2004, 1997; and Delgado 1982).

Of course, it is clear that limiting freedom of expression is a serious matter, and one that cannot be made without careful consideration, investigation, and public dialogue. But while it is certainly true that freedom of speech is an integral and paramount value for society, so is individual equality, dignity, and the freedom to live one's life free from unjustified intimidation and harassment on the basis of morally arbitrary characteristics, and to protect one's children from prejudiced hate mongers. In addition, freedom of conscience is also foundational to a liberal society. That is, the right to live according to one's comprehensive beliefs about the world and what gives value to life (be these beliefs religiously grounded or not) is basic and axiomatic. And toleration is of equal value. Therefore, I contend that freedom of speech needs to be balanced against, and cannot be allowed to trump, all other values at all times and places.

\section{Libel, defamation, slander and crying fire}

In fact, in many liberal democracies (including non-European ones) such a right does not trump all other such values. Many recognize the harm of hate speech and have legal provisions in response. For example, Britain limits abusive, insulting and threatening speech, Canada bans speech that is degrading, Australia bans that which humiliates or intimidates groups, and Germany bans speech that violates the dignity of or degrades a group. Various non-European countries also do the same, such as India and Israel. Many are guided by the International Covenant on Civil and Political rights, in particular article twenty that proscribes 'any advocacy of national, racial or religious hatred that constitutes incitement to discrimination' (Office of the Commissioner for Human Rights 1966). ${ }^{2}$ Indeed, Denmark too has laws against hate speech.

But less than this, many countries have legal penalties for banning what one might perhaps consider lesser infringements, such as defamation or libel. If making untruthful and damaging remarks about an individual is legally prohibited, then why would something worse in
2. Yet, there are other western countries, most notably the United States, which resists banning hate speech. There is a sort of entrenched absolutism about freedom of speech to which a wide number of Americans subscribe. This becomes clear in the common, pop, and also the intellectual culture of the USA. Indeed, the ACLU went so far as to defend Neo-Nazi's demand that they be able to march carrying Swastikas in a predominantly Jewish part of Chicago (Skokie) that contained holocaust survivors. 
many regards - such as spreading hate towards targeted minorities, highlighting their purported inherent inequalities, inferior and violent natures, and so on, be legally permissible? One might be tempted to bite the bullet here and argue that libel ought not to be legally and theoretically prohibited, and that one ought to allow people to slander and defame others publically at will. But what about yelling fire in a crowded theatre for one's simple amusement (knowing that there is no such fire)? Most agree that such (purposely untruthful) utterances ought to be prohibited and have a legal penalty attached to them. Why? The reason usually given is that it is a false statement that causes devastating and direct harm to people's lives. But, even if the harm caused by prejudiced speech is not as easy to see, it is nevertheless devastating and has just as far reaching harmful consequences.

\section{Democracy and dialogue}

In this part of my paper, I offer a transcendental argument for democracy. Indeed, the argument is for any form of a civilized global exchange and intercultural dialogue between nations. That is, I contend that caricatures such as the above weaken the social conditions that make possible a thriving democracy (i.e., participation) by marginalizing the already marginalized. They have further reach however. We do not live in isolated spheres, cut off from one another. What we say and do has impact much beyond our borders; this is clear from the response that the cartoons received from around the globe. In an interconnected world, the degree and weight of responsibility for what we say and do is that much greater. By marginalizing the already marginalized and perpetuating prejudiced stereotypes, the caricatures weaken the bonds of civility required for global international exchange and intercultural dialogue. They deteriorate the hope of mutual accommodation between various nations. Furthermore, I argue that the Danish cartoons are not somehow an isolated historical event; they perpetuate an Orientalist discourse about the nature of Islam and the "nonWest,' and hinder global intercultural dialogue and understanding between communities and nations.

Let me perhaps ask a basic and naïve question about the nature and goals of freedom of speech. And, let me ask whether such goals can be achieved without demeaning, degrading and spreading prejudice towards targeted groups. It might seem too obvious a question, but why do we think that freedom of speech is important? What does it allow us to do? John Stuart Mill famously points out that such a freedom allows us to critically examine and debate the merit of particular ideas; to scrutinize widely held and accepted dogmas. It is essential to the discovery of truth and falsity and to figure out what is of value, and what is not, in the market place of ideas. Politically, it allows to keep the powers that be accountable, to maintain an informed and educated citizenry: to hold open public debate and discussion, and is a fundamental requirement to the kind of participation that is critical in a democracy. It is indispensable to many aspects of our individual and collective lives as members of diverse communities, nations, and the globe at large.

But, can these goals be achieved without the need to mock, ridicule, stereotype, and publically humiliate and spread prejudice towards others? 
Yes, they can. If I want to argue that a particular interpretation of the Koran is problematic or distorted, or that I disagree with specific beliefs and practices of a particular group or community for a number of reasons, does that require that I be able to publically lampoon and feed animosity via prejudiced caricaturizations of such beliefs, especially if such beliefs are deeply held and thought to be sacred? Moreover, should such actions be a legally protected by the state? This seems to me akin to having a right to bullying people because the target of such prejudice are usually members of minority groups that do not enjoy the kind of social freedom and selfconfidence of the majority, and usually are the on-going historical targets of prejudice and discrimination. In fact, it seems to me the opposite, by allowing such speech we caricaturize the goals and ends of freedom of speech. They are in fact thwarted by such speech, if anything.

In terms of democracy, by legally making permissible harassment, vicious ad hominan attacks, social intimidation, and social alienation of large subsections of the population on the basis of their religion, gender or skin color, one does not encourage equal participation, one threatens its very existence. In fact, for these reasons, one might argue that hate speech thwarts the very social conditions that make possible the kind of society in which freedom of speech can flourish in the first place. Such a society requires standards of civility (and decency) that participants are held against in dialogue and discussion; it requires some form of social stability and a degree of harmony between various groups. But hate speech, by its nature, is aimed at destroying these conditions.

Indeed, a great number of objections against the caricatures of Islam and Muhammad were simply along those lines. A wide majority of Muslims around the globe did not and do not object to respectful criticisms of Islam; indeed, libraries are full of them. But what they object to are the harmful and prejudiced assumptions that the caricatures embodied. The point is not that people should not be free to express criticism towards particular religions and ideologies they find to be problematic, only that such criticisms should proceed in a civil manner with due consideration and respect, without biased stereotyping, name-calling, ad hominam attacks and other intimidation tactics. Indeed, I am bewildered at how placing a bomb in Mohammad's turban and depicting him as a suicide bomber is any form of civil objection to the manner in which Islam is appropriated by extremists; the same can be said for the cartoon about the Prophet exclaiming that 'we've run out of virgins.' Such cartoons are grounded in and work only to perpetuate prejudiced stereotypes that equate Islam and all Muslims with terrorism - which Muslims around the globe have been trying to dispel since 911. They create a social environment of conflict and intimidation for a community that already feels that its way of life is threatened. I do not see how such tactics incorporate people into the wider public and democratic sphere, as Rose argues. They have the opposite effect: the marginalized feel further marginalized and powerless.

As importantly, this kind of marginalization leads to social isolation and social alienation. These are perfect conditions for fundamentalists to recruit and indoctrinate those alienated with hate and propaganda; this is especially true in the case of young men. This begins a vicious cycle, as fundamentalists seek to further solidify the distance between "us and them." 
Civility and respect are not just important in creating the social conditions for a functioning democracy, they are critical to international intercultural relationships in general. As Vaclav Havel argues, we need to breath the spirit of intercultural dialogue in our everyday lives. Dialogue is paramount in today's changing global and multicultural environment, where ethnic and religious tensions can often run high, and where basic understandings may not be shared. It is the only mechanism that can foster and promote understanding between communities, which makes the goals of mutual cooperation between peoples more likely, and stable. Critically, dialogue is of vital importance as it is a key means for ensuring that the relationship between peoples proceeds on the basis of equality. We can ill afford the colonial luxury to assume that our perspective is the standard to which all must comply. The ideal of dialogue requires an effort to understand and appreciate others' perspectives and selfunderstandings in the hope of mutual recognition. It requires adopting an open-minded attitude towards others' traditions, in the hope of building a relationship of mutual trust, accommodation, and cooperation between diverse cultural communities. This ideal is more demanding than simply tolerating or having to put up with and endure other ways of life. However, being open to others' self-understandings does not necessarily mean that one agree with, convert to, or develop a personal preference for the particular views or practices in question. But it does require giving these serious and due consideration and being at least open to an acknowledgement of their worth.

Speech that is meant to lampoon, insult and stereotype does nothing to support such goals, but only increases the likelihood of even more conflict and division. This is certainly true with the above caricatures, they only serve to increase the divide between Muslim and non-Muslim nations. None of this is to say that we can always circumvent giving others offence. But, the norms of civility and respect (the transcendental conditions of democracy and dialogue) require giving due and serious consideration to other's perspectives and if offense cannot be avoided, we need to explain why such offense is inevitable and necessary. The action of publically depicting Muhammad as a suicide bomber is neither inevitable or necessary. In fact, on the contrary, it is an act of gratuitous offense. There are other ways of expressing frustrations about the nature of religious (or nonreligious) extremism without spreading prejudice and hateful attitudes ourselves.

Furthermore, let me emphasize that the manner in which the cartoons depict Muslims and Islam is not somehow an isolated event. It fits well into an established discourse that is deeply rooted in a historical power relationship between the West and non-West. This relationship is embedded in colonial and neo-colonial domination, exploitation, and oppression of weaker nations of the world. Such a discourse often relies on the realm of ideas as a means to exclude different peoples and ways of life from participation in important social, economic, and political arenas. The cartoons resonate with a variety of false oppositions that characterizes such a discourse; the non-West, especially Muslims, are, among other things, irrational, violent, uncivilized, misogynist, and hopelessly religious and anti-scientific. The West on the other hand, is freedom-loving, democratic, scientific, and the epitome 
of rationality. The cartoons serve to reinforce this image of Muslims as backward, religious, women-hating, violent thugs.

\section{Some prevalent objections}

There are a number of objections against my position. Here I consider some which I think are among the most prevalent.

\section{Liberal democracy: love it or leave it}

As I mentioned, both Rose and Randall argue that offense is simply the way that liberal democracies work and Muslims either tolerate such an offense, or leave. After all, Christians have to put up with their most cherished beliefs being lampooned; and, so, Muslims have to learn to bear the same things. This is the equal right to be harassed and bullied argument. There are number of problems here (apart from the harms of hate speech argument I have already discussed).

First, the situation of Christians is not the same as that of Muslims. Christians are a part of the dominant majority in Europe and North America. Muslims are not. In fact, most Muslims in Europe are a part of the economically, socially, and politically marginalized weaker class. This is apart from the Islamaphobia they face since 911 and a wider history of intolerance and historical prejudice. Harassing someone who is strong and has most of society on his side is different from harassing someone who is weak and has little going for him. The latter is called bullying. Secondly, there is a more fundamental issue for which Rose and Randall do not account. They simply take it for granted that the right to offend Christians (and others) is somehow an inalienable right in a liberal democracy. They fail to provide sufficiently good reason for this apart from, 'well, this is the way we do things around here, so like it or leave.' Just because this is the way we do things here (supposedly) does not necessarily mean that they ought to be done that way. Randall offers no argument for why liberal democracies cannot, or more importantly, should not change in this regard. Perhaps Muslim citizens and immigrants are on to something and civil discourse is to be admired. In other words, exactly why should Christians put up with such humiliation? The reason that it is a part of our tradition to harass, lampoon, and bully religious people is not to offer a good justification.

Let me emphasize that both Rose and Randall fail to treat Muslims citizens as equals. As citizens of a liberal democracy, they are, as anyone, entitled to voice their perspectives and judgements in the political domain. They are entitled to try and convince people of their perspectives. This is integral to the process of democracy. To tell them to 'like it or leave' is to treat them as second-class citizens.

\section{Artistic freedom}

In a liberal democracy, artistic expression is basic and foundational. As such, it is and ought to be my artistic freedom to be able to express myself in whichever way I desire, even if this means using profanities and obscenities to characterize that which others consider sacred. In fact, it is not only in my interest, but in the interest of society to be able to enjoy the fruits of such artistic labor. Artistic expression is an essential component of 
being human and a part of human nature. It is our highest achievement and defines what it is to be truly human. This is the line of argument often pursued by Salman Rushdie (see Parekh 1990).

I contend that this line of reasoning is problematic. I certainly acknowledge that art is an important and integral part of what it means to be human and I certainly believe that we ought to encourage such development in society. One can do this without at the same time acknowledging that artistic expression is of absolute value that overrides all other values in society, such as the freedom of others to live in an environment of peace in which they can raise their children without threat. As important is the value of freedom of conscience, which provides a safe space for others to practice their religions (or not) without interference. Now, I may find that I am only made fully human by writing a novel that satirizes, parodies, and pokes fun of the victims of the holocaust. But it is not at all clear to me why Jews, or society at large, need to tolerate any such work. I do not see why society needs to bear the burdens of the benefit and pleasure I derive from such a pursuit. My retort is along the same lines; while it is true that freedom of speech and artistic freedom are foundational, these too have limits. Such limits are defined by the freedom of other individuals to also pursue their goals without interference. Moreover, because something may be a part of human nature does not mean that we need to give it unrestrained license (e.g. aggression).

\section{The slippery slope: From here to totalitarianism}

But, the borders of the acceptable and the offensive are contested in a multicultural society, and often very difficult to define. This is where the second objection comes in. At first we begin with banning a few offensive words, then a few novels, and then, we end up in a totalitarian society. As Fleming Rose argues:

...I am sensitive about calls for censorship on the grounds of insult. This is a popular trick of totalitarian movements: Label any critique or call for debate as an insult and punish the offenders. That is what happened to... Alexander Sozhenitsyn, Natan Sharansky .... The regime accused them of anti-Soviet propaganda, just as some Muslims are labeling twelve cartoons in a Danish newspaper as anti-Islamic.

(Rose 2006: 19 February B01)

The objection is fallacious. It assumes that one set of events will logically, directly and automatically lead to another, without specifying exactly why this is the case. I fail to see how the claim that perpetuating prejudiced stereotypes that link Islam and all Muslims with terrorism is problematic to supporting a totalitarian state. There is no necessary empirical or logical correlation. First, let me take the empirical component. Most European countries as I noted, including Denmark itself, have laws against hate speech, and much lesser offences such as libel or defaming another. I do not see any empirical connection between these articles and Maoist support. Secondly, let me look at the purported conceptual connection. Such an assumption is theoretically unreasonable. We can argue for limits to 
freedom of speech fully within the conceptual and theoretical limits of liberalism and democracy (as I have done).

What is true however is that limiting freedom of speech is a serious issue, one that cannot be easily decided without resource to extensive study, research, and public and intercultural dialogue. As I acknowledge, such limits are often contested and difficult to arrive at in a multicultural society. This is an issue that we, as a society, need to arrive at together through dialogue and discussion. Nothing here implicates supporting a totalitarian political regime which sanctions the arbitrary abuse of political power.

\section{Conclusion}

In a decolonizing world, it is not as easy to claim that one's favored interpretations of particular values set the standards to which all must adhere in order to have a voice at the table. The debates over the cartoons, if nothing else, attest to such resistance. The conditions that make possible democracy and intercultural dialogue in general, at the global level, are bound by norms of mutual civility, respect, recognition, and, freedom of speech. The cartoons published by the Danish paper erode the very foundations that make possible such global dialogue. They perpetuate prejudiced stereotypes against Islam and Muslims and fall under hate speech; they deteriorate the social fabric of respect and recognition required for mutual accommodation and cooperation in today's global multicultural environment.

\section{References}

Ali, T. (2003), The Clash of Fundamentalisms, Crusades, Jihads, and Modernity. New York: Verso.

Carens, J. (2006), 'Free Speech and Democratic Norms in the Danish Cartoon Controversy', International Migration, 44: 5, pp. 33-42.

Buch-Andersen, T. (2006), Denmark row: The power of cartoons. 3 October. Retrieved December 7, 2008, from From BBC News World Web Site: http://news.bbc.co.uk/1/hi/world/europe/5392786.stm.

Delgado, R. and Stefancic, J. (2004), Understanding Words that Wound, Boulder, CO: Westview Press.

Delgado, R. and Stefancic, J. (1997), Must we defend The Nazis?: Hate Speech, Pornography and the First Amendment, New York City: New York University Press.

Delgado, R. (1982), 'Words that wound: A tort action for racial insults, epithets, and name-calling', Harvard C.R.C.L. Review, 17 p. 133.

Dworkin, R. (1984), Liberalism. In Michael Sandel (ed.), Liberalism and Its Critics. New York: New York University Press, pp. 60-79.

Hansen, R. (2006), 'The Danish Cartoon Controversy: A Defence of Liberal Freedom', International Migration, 44: 5, pp. 7-16.

Huntington, S. P. (1996), The Clash of Civilizations and the Remaking of Word Order. New York: Touchstone.

Kymlicka, W. (1995), Multicultural Citizenship: A Liberal Theory of Minority Rights, Oxford: Clarendon Press.

Madood, T. (2006), The Liberal Dilemma: Integration or Vilification, International Migration, 44: 5, pp. 4-7. 
Mill, J. S. (2008), On Liberty and other Essays. (John Gray, ed.). Oxford: Oxford University Press, pp. 5-132.

Office of the Commissioner for Human Rights (1966), International Covenant on Economic, Social and Cultural Rights. Retrieved December 7, 2008 from http://www.unhchr.ch/html/menu3/b/a_cescr.htm.

Parekh, B. (2006), 'Hate Speech: Is there a Case for Banning?', Public Policy Research, 12: 4, pp. 213-223.

Parekh, B. (1990), 'The Rushdie Affair: Research Agenda for Political Philosophy', Political Studies, XXXVII, pp. 695-709.

John, R. (1971), A Theory of Justice. Cambridge, Mass.: Harvard University Press.

Rawls, J. (1999), The Law Of Peoples: With The Idea of Public Reason Revisited, Cambridge, Mass.: Harvard University Press.

Rose, F. (2006), 'Why I published Those Cartoons', Washington Post, 19 February, p. B01

Taylor, C. (1995), The Politics of Recognition. In Philosophical Arguments, Cambridge, Mass.: Harvard University Press, pp. 225-256.

\section{Suggested citation}

Peetush, A. K. (2009), 'Caricaturizing Freedom: Islam, Offence, and The Danish Cartoon Controversy', Studies in South Asian Film and Media 1: 1, pp. 173-188, doi: 10.1386/safm.1.1.173/1

\section{Contributor details}

Ashwani Peetush's research focus is social and political philosophy; He is especially interested in multiculturalism, dialogue, and human rights.

Contact: Asst. Professor of Philosophy, Department of Philosophy, Wilfrid Laurier University, 75 University Avenue West, Waterloo, Ontario N2L 3C5, Canada.

Tel: 519.884.0710 Ext. 3874

Fax: 519.883.0991

E-mail: apeetush@wlu.ca 